\title{
New enterovirulent Escherichia coli serogroup 64474 showing antigenic and genotypic relationships to Shigella boydii 16
}

\begin{abstract}
Correspondence
Armando Navarro arnava@servidor.unam.mx
\end{abstract}

Received 26 August 2009 Accepted 13 January 2010

\author{
Armando Navarro, ${ }^{1}$ Carlos Eslava, ${ }^{1}$ Luis Manuel Perea, ${ }^{1}$ Alma Inzunza, ${ }^{1}$ \\ Gabriela Delgado, ${ }^{2}$ Rosario Morales-Espinosa, ${ }^{2}$ Thomas Cheasty ${ }^{3}$ \\ and Alejandro Cravioto ${ }^{4}$
}
${ }^{1}$ Departamento de Salud Pública, Facultad de Medicina, Universidad Nacional Autónoma de México, Ciudad Universitaria, Mexico City DF 04510, Mexico
${ }^{2}$ Microbiología y Parasitología, Facultad de Medicina, Universidad Nacional Autónoma de México, Ciudad Universitaria, Mexico City DF 04510, Mexico
${ }^{3}$ Laboratory of Gastrointestinal Pathogens, Health Protection Agency, London NW9 5EQ, UK
${ }^{4}$ International Centre for Diarrhoeal Disease Research, Bangladesh, Dhaka, Bangladesh

Studies based on the analysis of housekeeping genes indicate that Escherichia coli and all Shigella species, except for Shigella boydii type 13, belong to a single species. This study analysed the phenotypic and genotypic characteristics of $23 \mathrm{E}$. coli strains isolated in different countries from faecal specimens taken from children with diarrhoea. Strains were identified using the VITEK system and typed with rabbit sera obtained against 186 somatic and 53 flagellar E. coli antigens and against 45 Shigella somatic antigens. Biochemical analysis of these strains showed a typical $E$. coli profile with a defined reaction against both $E$. coli $\mathrm{O} 179$ and S. boydii 16 somatic antisera. Agglutination assays for flagellar antigens showed a response against $\mathrm{H} 2$ in 7 (30\%) strains, $\mathrm{H} 10$ in 2 (9\%) strains, H32 in 12 (52\%) strains and H34 in 2 (9\%) strains, demonstrating 4 serotypes associated with this new somatic antigen 64474 . A serum against one of these E. coli strains (64474) was prepared. Absorption assays of S. boydii 16 and E. coli 64474 antisera with $E$. coli $\mathrm{O} 179$ antigen removed the agglutination response against this 0179 antigen completely, while the agglutination titres against both S. boydii 16 and E. coli 64474 remained the same. Four (17\%) E. coli strains showed antimicrobial resistance to piperacillin only, one $(4 \%)$ to piperacillin and trimethoprim/sulfamethoxazole, one $(4 \%)$ to ciprofloxacin, nitrofurantoin and piperacillin, and two (9\%) strains were resistant to ciprofloxacin, norfloxacin, ofloxacin, piperacillin and trimethoprim/sulfamethoxazole. With regards to PCR assays, one (4\%) of the strains was positive for Shigella gene $i p a H$, one $(4 \%)$ for $i p a A$, two (9\%) for ipaB, one (4\%) for ipaD, two ( $9 \%)$ for sepA and three (13\%) for ospF. The $r f b$ gene cluster in the E. coli strains was analysed by RFLP and compared with the gene cluster obtained from S. boydii 16 . The $r f b$-RFLP patterns for all 23 E. coli strains were similar to those obtained for S. boydii 16 . The results from $\mathrm{PCR}$ tests to detect $r f b$ genes $w z x$ (encoding $\mathrm{O}$ unit flippase) and $w z y$ (encoding polymerase) belonging to a cluster related to the biosynthesis of the $S$. boydii 16-specific $O$ antigen were positive in $21(91 \%)$ and $22(96 \%)$ of the strains, respectively. PCR assays to detect $E$. coli virulence genes were also performed. These assays detected enterotoxigenic $E$. coli genes ItA 1 in 12 of the strains (52\%), st $1 \mathrm{a}$ in $4(17 \%)$, cfa1 in $6(26 \%)$, cs 1 in $1(4 \%)$, cs 3 in 3 $(13 \%), c s 13$ in $9(39 \%)$ and cs14 in $5(22 \%)$ of the strains. Results from the PFGE analyses confirmed the wide geographical distribution of these strains suggesting that $64474: \mathrm{H} 2$, $64474: \mathrm{H} 10,64474: \mathrm{H} 32$ and $64474: \mathrm{H} 34$ are new serotypes of $E$. coli strains with a defined virulence capacity, and share a common O antigen with S. boydii 16. 


\section{INTRODUCTION}

Escherichia coli is the most important aetiological agent of childhood diarrhoea and is a major public-health problem in developing countries (Davidson et al., 2002). Diarrhoeagenic E. coli comprise six major pathotypes: enteropathogenic E. coli, enteroinvasive E. coli (EIEC), enterotoxigenic E. coli (ETEC), enteroaggregative E. coli, diffusely adherent E. coli and Shiga toxin-producing E. coli (Nataro \& Kaper, 1998). Shigella is another human pathogen that is prevalent in less-developed countries where poor sanitation and lack of personal hygiene increase the incidence of disease (Kotloff et al., 1999; Davidson et al., 2002).

LPS is a key component of the outer membrane of Gramnegative bacteria that comprises three distinct regions: lipid A, an oligosaccharide core and commonly a repeat unit polysaccharide $\mathrm{O}$ antigen (Raetz \& Whitfield, 2002). E. coli serotyping indicates relatedness between clinical isolates and allows preliminary classification into pathotypes in the absence of molecular characterization. The highly variable nature of the $\mathrm{O}$ antigen provides the basis for serotyping, and the differentiation into $186 \mathrm{O}$ antigen forms (serogroups) that have been recognized in E. coli. Differentiation has led to the categorizing of $\mathrm{O} 174$ and $\mathrm{O} 175$ to temporary $\mathrm{O}$ groups $\mathrm{OX} 3$ and $\mathrm{OX} 7$, as well as the description of 11 new E. coli $\mathrm{O}$ groups that include verocytotoxin-producing E. coli O176, O177, O178, O179, O180 and O181 (Scheutz et al. 2004), and O182 to O186 (T. Cheasty, unpublished data).

Shigella strains are classified into four species Shigella dysenteriae, Shigella flexneri, Shigella boydii and Shigella sonnei, also known as subgroups $\mathrm{A}, \mathrm{B}, \mathrm{C}$ and $\mathrm{D}$, respectively (ESNC-IAMS, 1958). Based on antigenic variation in their $\mathrm{O}$ antigens, Shigella species are also typed into multiple serotypes. Despite some biochemical and antigenic differences, Shigella and E. coli have always been considered to be very closely related. Studies based on the analysis of housekeeping genes suggested that E. coli and Shigella belong to a single species (Pupo et al., 2000). This can be supported by studies that show the presence of common somatic antigens between E. coli and Shigella. The reported structures and sequences for 34 Shigella $\mathrm{O}$ antigens and for the corresponding E. coli $\mathrm{O}$ antigens that have significant antigenic cross-reactions with Shigella $\mathrm{O}$ antigens indicate that 21 of the 34 Shigella $\mathrm{O}$ antigens and associated gene clusters are identical or closely related to those found in $E$. coli. However, $12 \mathrm{O}$ antigen gene clusters are unique to Shigella and are not related to other E. coli $\mathrm{O}$ antigen gene clusters (Liu et al., 2008; Li et al., 2009); S. boydii 16 is one of these.

Over the last 15 years, approximately 10000 E. coli strains isolated from different sources have been typed with rabbit sera in the Laboratory of Enteric Pathogens in the Department of Public Health, National Autonomous University of Mexico (Departamento de Salud Pública, UNAM) utilizing sera obtained against O1 to O181 E. coli antigens and against 45 of the Shigella antigenic groups (13 of S. dysenteriae, 13 of S. flexneri, 18 of S. boydii and $1 S$. sonnei serotype). This typing scheme has been extended to include five new E. coli O sera, O182 to O186 (T. Cheasty, unpublished data). Using the expanded serotyping scheme, 23 strains classified biochemically as E. coli were identified serologically as having both E. coli O179 and S. boydii $16 \mathrm{O}$ antigens. The present study was designed to try to explain the significance of these serological cross-reactions.

\section{METHODS}

Strains. The 23 E. coli strains used in this study were isolated from children with diarrhoea from 3 different geographical areas. Ten strains were isolated from children in Mexico, eleven in Egypt (kindly provided by Dr Stephen Savarino, Naval Medical Research Center, Silver Spring, MD, USA) and two in Bangladesh. S. boydii 16 (G1219) and E. coli O179: H8 (E43478) were used as reference strains.

Biochemical identification. The identity of the 23 strains was confirmed using both the VITEK automated system (bioMérieux) and standard methods (Barrow \& Feltham, 1993).

Serotyping. The strains were serotyped by agglutination assays (Ørskov \& Ørskov, 1984) using 96-well microtitre plates and rabbit serum (SERUNAM) obtained against 181 somatic antigens and 53 flagellar antigens for $E$. coli, and against 45 somatic antigens for Shigella species. Rabbit serum against E. coli strain 64474 : H32 was also prepared (Ewing, 1986). In addition, the serotyping of the E. coli strains was confirmed with 186 anti-O E. coli and 45 anti-O Shigella sera from the Laboratory of Gastrointestinal Pathogens, Department of Gastrointestinal, Emerging and Zoonotic Infections, Centre for Infections, Health Protection Agency, London, UK.

\begin{abstract}
Absorption assays. Rabbit sera prepared against S. boydii 16, E. coli O179 and E. coli 64474 strains were absorbed against homologous and heterologous antigens according to the method described by Ewing (1986). In brief, smooth colonies grown overnight at $37{ }^{\circ} \mathrm{C}$ on blood agar plates were used to inoculate trypticase soy agar plates, which were incubated overnight at $37{ }^{\circ} \mathrm{C}$. Bacteria were harvested into $10 \mathrm{ml}$ $0.15 \mathrm{M} \mathrm{NaCl}$ (saline) solution, heated to $100{ }^{\circ} \mathrm{C}$ for $1 \mathrm{~h}$ and adjusted to a final concentration of $9 \times 10^{8}$ bacteria $\mathrm{ml}^{-1}$. The antigens were incubated at $50{ }^{\circ} \mathrm{C}$ with the homologous and heterologous serum samples for $2 \mathrm{~h}$, the mixture was then centrifuged (6000 $\mathrm{g}$ for $10 \mathrm{~min}$, $4{ }^{\circ} \mathrm{C}$ ) and the serum tested for agglutinating activity.
\end{abstract}

Antimicrobial susceptibility. Susceptibility to different antimicrobial agents was determined using a VITEK AutoMicrobic system (VITEK-AMS; bioMérieux) with GNS 604 cards containing amikacin (2-32 $\left.\mu \mathrm{g} \mathrm{ml} \mathrm{m}^{-1}\right)$, amoxicillin/clavulanic acid $\left(4 / 2-16 / 8 \mu \mathrm{g} \mathrm{ml}^{-1}\right)$, cefazolin (4-64 $\mathrm{g} \mathrm{ml}^{-1}$ ), cefepime (4-16 $\mu \mathrm{g} \mathrm{ml} \mathrm{ml}^{-1}$ ), ceftazidime (4-64 $\left.\mu \mathrm{g} \mathrm{ml}^{-1}\right)$, ceftriaxone $\left(16-128 \mu \mathrm{g} \mathrm{ml}^{-1}\right)$, cefuroxime $(4-64 \mu \mathrm{g}$ $\left.\mathrm{ml}^{-1}\right)$, ciprofloxacin $\left(1-4 \mu \mathrm{g} \mathrm{m} l^{-1}\right)$, gentamicin $\left(0.5-8 \mu \mathrm{g} \mathrm{ml}{ }^{-1}\right)$, meropenem $\left(2-8 \mu \mathrm{g} \mathrm{ml}^{-1}\right)$, nitrofurantoin $\left(32 \mu \mathrm{g} \mathrm{ml}^{-1}\right)$, norfloxacin (4-8 $\mu \mathrm{g} \mathrm{ml}^{-1}$ ), ofloxacin $\left(1-10 \mu \mathrm{g} \mathrm{ml} \mathrm{ml}^{-1}\right)$, piperacillin $(8-64 \mu \mathrm{g}$ $\left.\mathrm{ml}^{-1}\right)$, ticarcillin/clavulanic acid $\left(32 / 2-128 / 2 \mu \mathrm{g} \mathrm{ml}^{-1}\right)$ and trimethoprim/sulfamethoxazole (2/38-8/152 $\left.\mu \mathrm{g} \mathrm{ml} \mathrm{m}^{-1}\right)$. E. coli ATCC 25922 and Staphylococcus aureus ATCC 25923 were used as control strains.

Virulence genes. PCR assays were used to determine the presence of virulence genes, in a large virulence plasmid, which were directly involved with pathogenic entry into epithelial cells and invasive phenotypes observed in the pathogenesis of Shigella strains: ipaAipaD genes, which encode Ipa proteins that induce cytoskeletal 
rearrangements required for bacterial entry into epithelial cells (Ménard et al., 1996); the sepA gene, which encodes a secreted serine protease of the autotransporter family; osp $\mathrm{B}$ and $o s p \mathrm{~F}$ genes, which encode uncharacterized outer Shigella proteins; and the ipaH gene, which is also associated with virulence (Venkatesan et al., 2001). The primers used in this study are shown in Table 1. ETEC genes for colonization factor antigens CFA1, CS1, CS3, heat-labile (LTA1) and heat-stable (STa, $\mathrm{STb}$ ) toxins were amplified using specific primers as reported by Bekal et al. (2003) and Schultsz et al. (1994). Genes encoding CS13 (PCF O9) and CS14 (PCF O166) were also examined by PCR (Sjöling et al., 2007), as were the O unit flippase ( $w z x)$ and polymerase $(w z y)$ genes for S. boydii O16-specific antigen biosynthesis (Liu et al., 2006).

rfb-RFLP. A single colony of each E. coli strain was grown in LuriaBertain broth (Difco) at $37{ }^{\circ} \mathrm{C}$ in a shaking incubator for $18 \mathrm{~h}$, and the culture used for DNA isolation and PCR amplification. Chromosomal DNA was isolated using the DNeasy blood and tissue kit (Qiagen). Oligonucleotides described by Wang \& Reeves (1998) were used to amplify the $\mathrm{O}$ antigen gene cluster (Table 1). Long PCR was carried out with the Expand long template PCR system (Roche). The PCR was carried out as follows: a single denaturation step at $94{ }^{\circ} \mathrm{C}$ for $2 \mathrm{~min}$; 30 cycles of denaturation at $94{ }^{\circ} \mathrm{C}$ for $10 \mathrm{~s}$, annealing at $64{ }^{\circ} \mathrm{C}$ for $30 \mathrm{~s}$ and extension at $68^{\circ} \mathrm{C}$ for $15 \mathrm{~min}$; an additional extension step at $68{ }^{\circ} \mathrm{C}$ for $7 \mathrm{~min}$. A $35 \mu \mathrm{l}$ aliquot of PCR product was digested with $2 \mathrm{U}$ HincII (Invitrogen) in the supplied buffer. After overnight incubation at $37^{\circ} \mathrm{C}$, restriction fragments were resolved by electrophoresis on $1.3 \%$ agarose gel (agarose 1000;
Invitrogen). Fragment sizes were estimated using lambda ladder (Invitrogen).

PFGE. Genomic DNA for PFGE analysis was prepared using $1.5 \%$ low-melting-point agarose (Sea Plaque GTG; FMC Bioproducts) and macro restriction analysis of XbaI-digested total DNA was carried out as described by Goering (1993). The digested DNA was analysed by electrophoresis in $1.0 \%$ agarose, $0.5 \times \mathrm{TBE}$, with a Chef Mapper pulsed-field system (Bio-Rad) for $18 \mathrm{~h}$ at $6 \mathrm{~V} \mathrm{~cm}^{-1}$ with switching times from 2.16 to 54.17 s. Salmonella enterica serotype Braenderup DNA was restricted with $\mathrm{Xba \textrm {I }}$ as standard and used as DNA size markers. Gels were photographed under UV transillumination after staining with ethidium bromide $\left(1 \mu \mathrm{g} \mathrm{ml}^{-1}\right)$. Identical chromosomal banding patterns were considered to represent the same strain. Isolates that differed by three or fewer restriction fragments were classified as subtypes of the same strain, while organisms differing by more than three restriction fragments were considered sufficiently divergent to be considered as a separate strain (Matushek et al., 1996; Goering, 1993). Similarity relationships were assessed by the UPGMA method.

\section{RESULTS}

\section{Identification and serotyping}

The E. coli strains were isolated from 23 faecal samples from children with diarrhoea in 3 different geographical

Table 1. Oligonucleotide primers used in the PCR assay

\begin{tabular}{|c|c|c|c|c|c|}
\hline Primer & Forward sequence $\left(5^{\prime} \rightarrow 3^{\prime}\right)$ & Reverse sequence $\left(5^{\prime} \rightarrow 3^{\prime}\right)$ & $\begin{array}{r}\text { Target } \\
\text { gene }\end{array}$ & $\begin{array}{l}\text { Product } \\
\text { size }(b p)\end{array}$ & Reference \\
\hline CFAI & GGT GCA ATG GCT CTG ACC ACA & GTC ATT ACA AGA GAT ACT ACT & $c f a I$ & 479 & Bekal et al. (2003) \\
\hline CS3 & GGG CCC ACT CTA ACC AAA GAA & CGG TAA TTA CCT GAA ACT AAA & $\operatorname{cs} 3$ & 401 & Bekal et al. (2003) \\
\hline CS13 & GGG ACT GCC ACA ATG AAT TT & CAG CAC CAC CTG CTG ATT TA & csl3 & 178 & Sjöling et al. (2007) \\
\hline CS14 & TTT GCA ACC GAC ATC TAC CA & CCG GAT GTA GTT GCT CCA AT & csl4 & 162 & Sjöling et al. (2007) \\
\hline ST Ia & TCT GTA TTA TCT TTC CCC TC & ATA ACA TCC AGC ACA GGC & stla & 186 & Schultsz et al. (1994) \\
\hline ST Ib & CCC TCA GGA TGC TAA ACC AG & TTA ATA GCA CCC GGT ACA AGC & stlb & 166 & Schultsz et al. (1994) \\
\hline ipaH & $\begin{array}{l}\text { TCT CGG CAC GTT TTA } \\
\text { ATA GTC TGG }\end{array}$ & TAA ATC TGC GGG CCG TGG TAG TC & $i p a H$ & 446 & This study \\
\hline ipaA & CCC CGG GGC CAA TGA GAA AAC & AGG CCT GTG TCC CCG AGA AAG AGA & $i p a A$ & 400 & This study \\
\hline ipaB & ACT CGC CCC AGA TTC ACC AGA & GCC CCA AGT ATT TTC CCA ACA CA & $i p a B$ & 447 & This study \\
\hline ipaJ & TTT GGC GAG GAA GCA GAT G & GTG GAG GCC GAC AGG AAC T & $i p a J$ & 460 & This study \\
\hline sepA & GGA GCG CCG GGA GAC CTA & TGC CGC ATC GAG TTT CAG TTT TT & $\operatorname{sep} A$ & 423 & This study \\
\hline ospF & $\begin{array}{l}\text { CTC AGA GTA AGG GGG } \\
\text { ATT TTG TTG }\end{array}$ & $\begin{array}{l}\text { CTC TTG CCT TTC ACT } \\
\text { TCC ATC TCG }\end{array}$ & ospF & 401 & This study \\
\hline ospB & $\begin{array}{l}\text { AAA GCG AAA ATA AAA } \\
\text { ACA GTA AAC }\end{array}$ & $\begin{array}{l}\text { TAG GGA AAA AGC TCT } \\
\text { TGA CCA TAG }\end{array}$ & $o s p B$ & 404 & This study \\
\hline $\begin{array}{l}\text { WL 387- } \\
388\end{array}$ & TTT CAT TTG TCT TGG GAG & ATC TCC CTT ATT YGC GTA T & $w z x$ & 910 & Liu et al. (2006) \\
\hline $\begin{array}{l}\text { WL 393- } \\
394\end{array}$ & TTC ACC GCA TAT CTA ATC & TAT GGC GTG GTG TTT ATG & $w z y$ & 777 & Liu et al. (2006) \\
\hline $\begin{array}{l}\text { rfb } 482- \\
412\end{array}$ & $\begin{array}{c}\text { CAC TGC CAT ACC GAC GAC } \\
\text { GCC GAT CTG TTG CTT GG }\end{array}$ & $\begin{array}{l}\text { ATT GGT AGC TGT AAG CCA } \\
\text { AGG GCG GTA GCG T }\end{array}$ & $r f b$ & 11000 & $\begin{array}{l}\text { Wang \& Reeves } \\
\text { (1998) }\end{array}$ \\
\hline
\end{tabular}


regions: there were 10 (43\%) strains from Mexico, 9 of which were isolated in 1985 and 1 in 1998; 11 (48\%) E. coli strains from Egypt, of which 1 strain was isolated in 1997, 2 in 1999 and 8 in 2006; and 2 (9\%) E. coli strains from Bangladesh isolated in 2007.

All 23 strains were identified as E. coli by VITEK automated and manual identification procedures. Using automated identification, all E. coli strains showed the typical biochemical profile of E. coli: glucose, lactose, maltose, raffinose, sorbitol and xylose were fermented; sucrose was not fermented; and lysine was decarboxylated. Using manual identification, both gas production from glucose fermentation in the 23 strains and indole production were confirmed. These biochemical assays were consistent with E. coli identification but not with the identification of Shigella.

Serotyping of the E. coli strains with 186 anti-O E. coli and 45 anti-O Shigella sera showed a positive agglutination reaction against E. coli O179-specific and $S$. boydii 16specific sera, and against a rabbit serum prepared with $E$. coli strain 64474 (Table 2). A serological reaction was also shown against flagellar antigens $\mathrm{H} 2$ in 7 strains (30\%), $\mathrm{H} 10$ in $2(9 \%)$ strains, H32 in $12(52 \%)$ strains and H34 in $2(9 \%)$ strains.

\section{Absorption assays}

To evaluate the presence of common epitopes between E. coli O179, S. boydii 16 and the 23 E. coli strains from this study, serum samples prepared against E. coli O179, S. boydii 16 and $E$. coli strain 64474 were absorbed with homologous and heterologous antigens. Absorption of $S$. boydii 16 serum with the heterologous E. coli O179 antigen removed only the reaction against the O179 antigen. In contrast, when $S$. boydii 16 antiserum was absorbed with either S. boydii 16 or E. coli 64474 antigens, the agglutination was removed completely for both $S$. boydii 16 and E. coli $\mathrm{O} 179$ antigens. Absorption of sera prepared against E. coli $\mathrm{O} 179$ with either S. boydii 16 or E. coli 64474 antigens showed a significant reduction in the agglutination titre $(1: 3200$ to $1: 1600)$ when tested against the homologous antigen (O179), and a negative response against both the $S$. boydii 16 and E. coli 64474 antigens.
Absorption assays of sera prepared against E. coli 64474 with E. coli O179 antigen showed a negative response against the E. coli $\mathrm{O} 179$ and a significant decrease in the agglutination titres against E. coli 64474 and S. boydii 16 antigens (Table 2).

\section{Antimicrobial susceptibility}

Eight (35\%) of the twenty-three E. coli 64474 strains showed antimicrobial resistance principally to piperacillin. Four $(17 \%)$ E. coli strains from Egypt showed antimicrobial resistance to piperacillin only. One $(4 \%)$ of the Mexican strains was resistant to both piperacillin and trimethoprim/sulfamethoxazole antimicrobials. One $(4 \%)$ strain from Egypt was resistant to ciprofloxacin, nitrofurantoin and piperacillin, and two (9\%) E. coli strains from Bangladesh were resistant to five antimicrobial agents (ciprofloxacin, norfloxacin, ofloxacin, piperacillin and trimethoprim/sulfamethoxazole).

\section{Virulence genes}

PCR assays to determine the presence of Shigella virulence genes gave positive results for $o s p F$ in three $(13 \%)$ strains, $i p a B$ and sepA in two (9\%) strains, and $i p a \mathrm{H}$, ipaA and $i p a D$ in one $(4 \%)$ strain. The $23 \mathrm{E}$. coli strains were negative for $i p a C, i p a J$ and $o s p B$ genes. With regard to ETEC genes, $l t A 1$ and st $1 a$ were present in $12(52 \%)$ and $4(17 \%)$ of the strains, respectively (Fig. 1). Colonization factor $c f a 1$, cs 1 and $c s 3$ was identified in six (26\%), one (4\%) and three (13\%) strains, respectively, while cs13 was found in nine (39\%) and cs14 in five (22\%) strains. The st1b gene was not detected. Assays to detect the $w z x$ and $w z y$ genes for $S$. boydii $16 \mathrm{O}$ antigen biosynthesis were positive in $21(91 \%)$ and $22(96 \%)$ strains, respectively. Both $w z x$ and $w z y$ genes were identified in 10 (43\%) of the Mexican strains, as well in the $2(9 \%)$ Bangladeshi E. coli strains. In terms of the Egyptian strains, $9(39 \%)$ were positive for the $w z x$ gene and $10(43 \%)$ for the wzy gene.

\section{PFGE}

PFGE analysis (Fig. 1) of the 23 E. coli (64474, S. boydii 16) strains showed 18 electrophoretic types. Three main

Table 2. Agglutination titres of unabsorbed and absorbed E. coli 0179,64474 and S. boydii 16 sera

\begin{tabular}{|c|c|c|c|c|c|c|c|c|c|}
\hline \multirow[t]{3}{*}{ Antigen } & \multicolumn{3}{|c|}{ Titres of unabsorbed sera } & \multicolumn{6}{|c|}{ Titres of sera absorbed with boiled cultures } \\
\hline & \multirow[t]{2}{*}{ E. coli 0179} & \multirow[t]{2}{*}{ E. coli 64474} & \multirow[t]{2}{*}{ S. boydii 16} & \multicolumn{2}{|c|}{$\begin{array}{c}\text { E. coli } 0179 \text { absorbed } \\
\text { with: }\end{array}$} & \multicolumn{2}{|c|}{$\begin{array}{c}\text { E. coli } 64474 \text { absorbed } \\
\text { with: }\end{array}$} & \multicolumn{2}{|c|}{$\begin{array}{l}\text { S. boydii } 16 \text { absorbed } \\
\text { with: }\end{array}$} \\
\hline & & & & $\begin{array}{c}\text { S. boydii } \\
16\end{array}$ & $\begin{array}{r}\text { E. coli } \\
64474\end{array}$ & $\begin{array}{r}\text { E. coli } \\
\text { O179 }\end{array}$ & $\begin{array}{c}\text { S. boydii } \\
16\end{array}$ & $\begin{array}{r}\text { E. coli } \\
\text { O179 }\end{array}$ & $\begin{array}{r}\text { E. coli } \\
64474\end{array}$ \\
\hline E. coli $\mathrm{O} 179$ & $1: 3200$ & $1: 800$ & $1: 800$ & $1: 1600$ & $1: 800$ & - & - & - & - \\
\hline S. boydii 16 & $1: 1600$ & $1: 3200$ & $1: 6400$ & - & - & $1: 800$ & - & $1: 3200$ & - \\
\hline E. coli 64474 & $1: 1600$ & $1: 1600$ & $1: 3200$ & - & - & $1: 1600$ & - & $1: 1600$ & - \\
\hline
\end{tabular}


clusters (I, II, III) were identified within the dendrogram. Cluster I was divided into three subgroups (A, B, C). Subgroup A included the six strains isolated in Egypt in 2006. Five of these Egyptian strains harboured the ltA1, wzx and $w z y$ genes. The majority of the ten strains in subgroup B were isolated in Mexico in 1985. Six strains of subgroup $\mathrm{B}$ harboured the $l t A 1$ gene; eight the $w z x$ gene and nine the wzy gene. Finally, subgroup $\mathrm{C}$ included the two strains isolated in Bangladesh and Egypt in 2007 and 2006, respectively. These strains also harboured genes $w z x$ and $w z y$, but only the strain isolated from Egypt was positive for the $l t A 1$ gene.

The reference strain of $S$. boydii 16 and three strains isolated in different years, namely two in Egypt 1999 and one in Mexico 1998, formed cluster II. The $w z x$ and $w z y$ genes were detected in the three E. coli strains in this cluster with two Egyptian strains harbouring the ltA1 also. Finally, cluster III included only one of the strains isolated in Egypt in 1997 and the E. coli O179:H8 reference strain. The strain isolated in Mexico harboured genes $w z x$ and $w z y$, which were not detected in the E. coli O179: H8 type strain. Although these results show a high degree of genetic diversity among the different E. coli strains, serological characterization suggests four new possible serotypes in strains isolated from children with diarrhoea (64474: H32/ 64474 : H2/64474 : H10/64474 : H34).

\section{RFLP}

The $r f b$-RFLP HincII restriction pattern of the $23 \mathrm{E}$. coli strains used in the study was the same as that obtained for S. boydii 16 (Fig. 2). This pattern had six bands (2300, 2000,1400,1000, 500 and 360 bp) and is clearly different from that obtained for E. coli $\mathrm{O} 179$ with five bands (3800, 2700, 1700, 1250 and $500 \mathrm{bp})$.

\section{DISCUSSION}

In this study we have characterized the genetic and phenotypic profiles of $23 \mathrm{E}$. coli enterotoxigenic strains

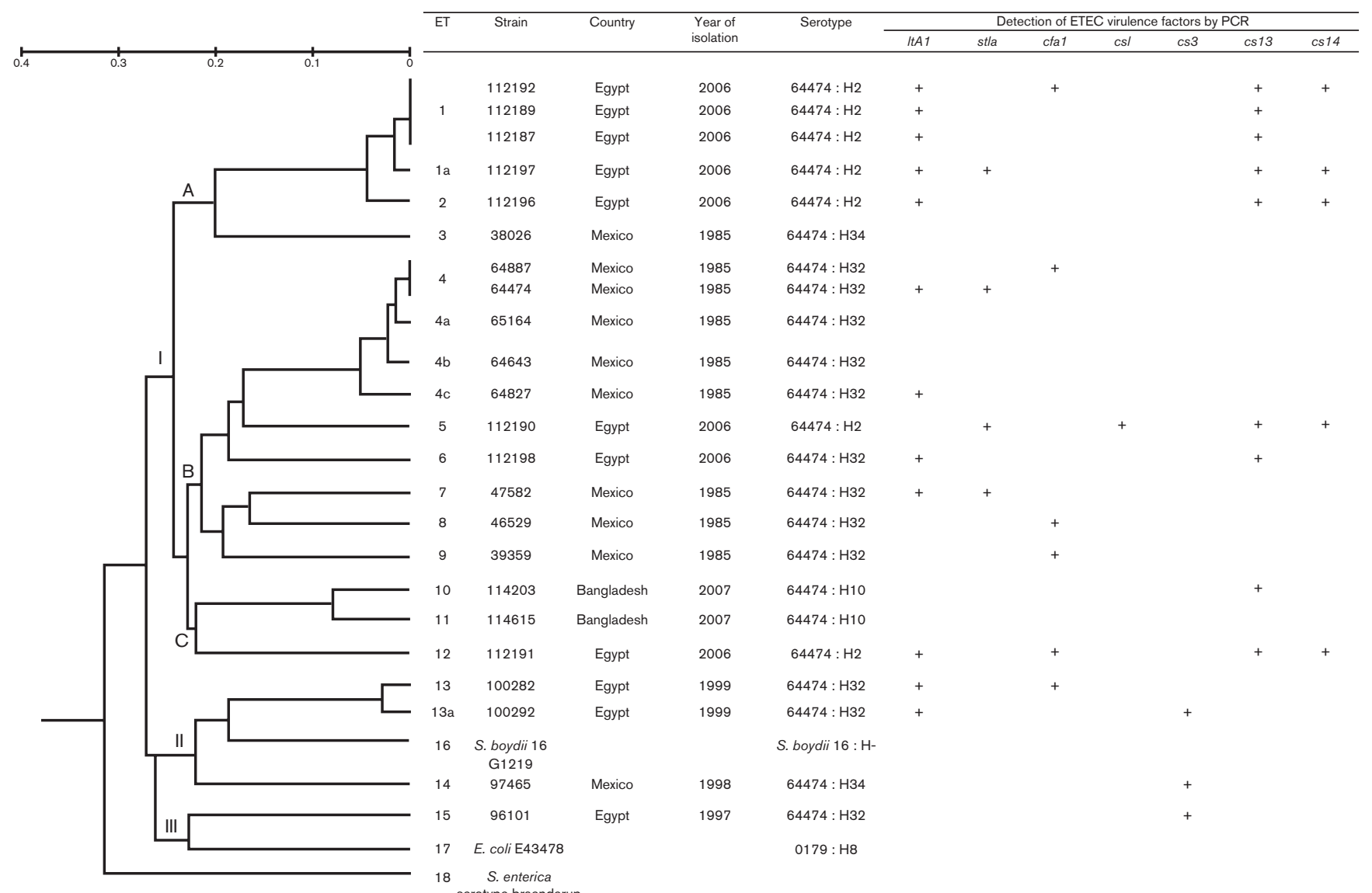

Fig. 1. Dendrogram showing the genetic relationship of the PFGE profiles of $E$. coli. The dendrogram was constructed using Nei's minimum distance by the UPGMA method. The country of origin, year of isolation, serotype and ETEC virulence factors identified in E. coli 64474 are shown. + , Gene detected; ${ }^{*}$, numbers in parentheses are the percentages of positive samples detected; ET, electrophoretic type. 
$\begin{array}{llllllllllllllllllllllllll}1 & 2 & 3 & 4 & 5 & 6 & 7 & 8 & 9 & 10 & 11 & 12 & 13 & 14 & 15 & 16 & 17 & 18 & 19 & 20 & 21 & 22 & 23 & 24 & 25 & 26\end{array}$

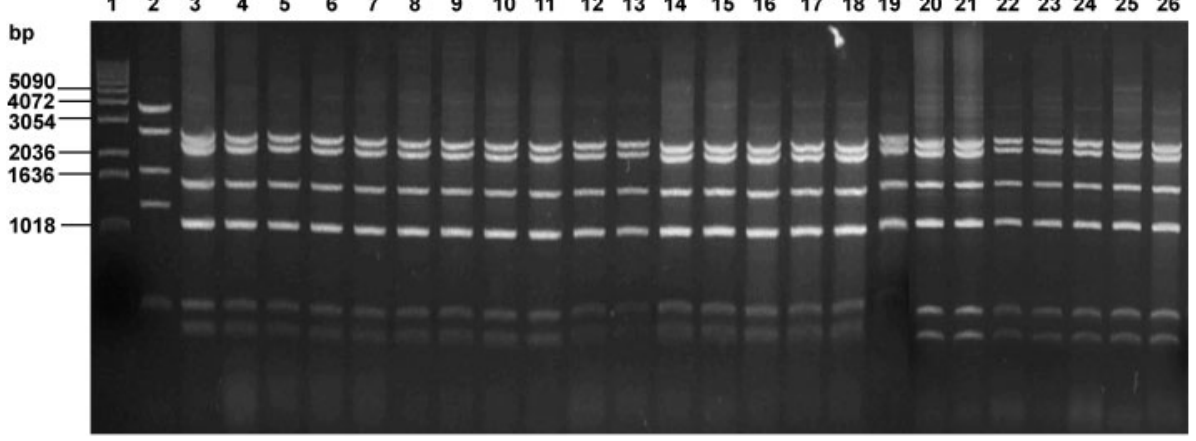

Fig. 2. Agarose gel (1.3\%) electrophoresis showing the comparison of the rfb-RFLP pattern with Hincll for E. coli O179, S. boydii 16 and E. coli $64474: \mathrm{H} 2,64474: \mathrm{H} 10,64474: \mathrm{H} 32$ and $64474: \mathrm{H} 34$. Lane 1, molecular size marker (1 kb ladder; Invitrogen); lane 2, E. coli O179; lane 3, S. boydii 16; lanes 4 to 26, E. coli 38026, 39359, 46529, 47582, 64643, 64474, 64827, 64887, 65164, 97465, 96101, 100282, 100292, 112187, 112189, 112190, 112191, 112192, 112196, 112197, 112198,114203 and 114615.

isolated at different times from patients suffering from diarrhoea in Egypt, Mexico and Bangladesh. All of the strains presented typical biochemical characteristics of E. coli, such as gas production from glucose fermentation, lactose, maltose, raffinose, sorbitol and xylose fermentation, indole production and decarboxylation of lysine, and all shared identity with the $S$. boydii 16 somatic antigen as shown by serological tests and by specific absorption assays. However, in contrast to $S$. boydii 16, which like all Shigella strains is non-motile due to a deletion of the flhDC flagellar master operon (Tominaga et al., 2005), the E. coli 64774 strains were motile and had specific flagellar antigens as detected by serological assays. The majority of the strains isolated in Egypt had an $\mathrm{H} 2$ antigen, the strains isolated in Mexico an $\mathrm{H} 32$ antigen and those isolated in Bangladesh an H10 antigen. The somatic antigen of strain E. coli 64474 was found to be identical to that of S. boydii 16 and to be closely related to that of E. coli O179. This is not a rare event since numerous reports have documented the presence of common or closely related somatic antigens between different serotypes of E. coli and Shigella, especially among strains with invasive capacity in both groups (Liu et al., 2008; Li et al., 2009). These include: S. dysenteriae 3 and E. coli O124 (Jonsson et al., 2006); S. boydii 15 and E. coli O112ab, which have a similar $\mathrm{O}$ antigen structure (Perepelov et al., 2008a); S. dysenteriae 2 and E. coli O112ac, which are identical except the E. coli polysaccharide lacks an $\mathrm{O}$ acetyl group (Perepelov et al., 2008b); S. boydii 1 and E. coli O149 (Liu et al., 2008); S. boydii 3 and E. coli O167 (Linnerborg et al., 1997); S. boydii 8 and E. coli O143 (Landersjö et al., 1996); and S. dysenteriae 11 and E. coli O29, which have the same $\mathrm{O}$ structure and antigenic cross-reactivity (Perepelov et al., 2006). In order to confirm whether the antigenic cross-reactivity observed between the studied $E$. coli strains and $S$ boydii 16 using specific sera was related to the biosynthesis of the $\mathrm{O}$ antigen genes of $S$. boydii 16, an analysis was carried out to determine the presence of the $w z x$ (flippase) and $w z y$ (polymerase) genes that are associated with this characteristic. The presence of the $w z x$ and $w z y$ genes in the E. coli strains used in the study confirmed the existence of a common epitope similar to that found in the S. boydii 16 pentasaccharide $\mathrm{O}$ unit antigen (Liu et al., 2006).

The 23 E. coli strains showed an RFLP pattern of the $r f b$ locus similar to that of $S$. boydii 16, thus confirming the similarity of the somatic antigen in the bacteria studied. Some studies have reported RFLP patterns similar to the cluster of the $r f b$ gene in Shigella and EIEC, such as the pattern between $S$. dysenteriae 2 and E. coli O112, S. dysenteriae 3 and E. coli O124, S. dysenteriae 8 and E. coli $\mathrm{O} 38$, S. boydii 12 and E. coli $\mathrm{O} 7$, and S. boydii 4 and $E$. coli O53 (Coimbra et al., 1999, 2000).

The PCR assays used in this study to determine the pathogenic type of the E. coli strains (Nataro \& Kaper, 1998) showed that they belonged to the enterotoxigenic group since they harboured both genes for the production of heat-labile and heat-stable enterotoxins, and for the production of specific colonization factors. The presence of both colonization factors CS13 and CS14 in some strains has been reported in Latin America (Paniagua et al., 1997), South-East Asia (Qadri et al., 2000) and Australia (Heuzenroeder et al., 1990).

E. coli strains with $S$. boydii 16 antigens have also been found in faecal samples from healthy birds and dairy cattle, which are part of ongoing studies to determine the burden of zoonotic transmission of pathogens in humans associated with diarrhoeal disease. This mechanism could be similar to that described for the transmission of E. coli $\mathrm{O} 157$ from cattle and sheep to humans (Chapman et al., 1997; Hancock et al., 1997). The lack of sanitation and personal hygiene, together with close contact between cattle and birds could be a viable transmission route for these bacteria in developing areas of the world. 
The PFGE analysis of the strains in this study indicates a clustering by geographical region, with the majority of ETEC strains isolated in Egypt in 2006 clustering in subgroup A, the strains isolated in Mexico clustering in subgroup B and those isolated in Bangladesh clustering in subgroup C. The strains from Egypt contained the Shigella plasmid virulence genes $(o s p F, \operatorname{sep} A, i p a H, i p a A)$, as well as the characteristic ETEC genes stla, cs1, cfa1, cs13, sc14 and $l t A 1$. This is suggestive that the acquisition of the Shigella plasmid genes by the ETEC strains via a mechanism of horizontal gene transfer (Gogarten et al., 2002; Reid et al., 2000). In addition, the transfer of the O antigen gene cluster from $S$. boydii 16 to the ETEC strains, thereby generating new strains with genetic and phenotypic characteristics, was also shown. Plasmids are known to cross species barriers enabling them to be highly effective vehicles for horizontal gene transfer between bacteria that coexist in a specific environment over a determined period of time such as the intestine (EscobarPáramo et al., 2003; Schubert et al., 2009). Acquisition and loss of functions by bacteria could yield betteradapted pathogenic variants, such as EIEC and Shigella (Peng et al., 2009), and increase the ability to adapt to a human host making them successful human pathogens through convergent evolution from diverse genomic backgrounds.

The categorization of these ETEC strains into three distinct clusters suggests that the emergence of these new serotypes is a phenomenon that has taken place more than once in the evolution of E. coli. Similar events to those reported in this study have been shown to occur in Shigella species, which suggests that their involvement with the evolution of E. coli has not been an isolated incident (Pupo et al., 2000; Rolland et al., 1998). The lack of drug resistance, and in particular multidrug resistance, amongst the majority of the studied strains was interesting. All were clinical isolates and the majority were sensitive to the various antimicrobials tested. In contrast, however, two E. coli 64474 Bangladesh strains (included in the cluster II subgroup C) showed a resistance pattern similar to that reported by Qadri et al. (2005) in E. coli strains isolated from clinical cases from the same country. On the basis of this the persistence of $E$. coli resistant clones in that region is suggested. With respect to the Mexican E. coli strains (cluster II subgroup B), all except one were sensitive to the antimicrobials tested in the study. This observation differs from those described by Estrada-García et al. (2005) and Amábile-Cuevas et al. (2010) in studies performed in Mexico, who reported resistance to ciprofloxacin, ampicillin, trimethoprim/sulfamethoxazole and tetracycline by E. coli strains isolated from clinical cases and environmental samples. The Mexican E. coli 64474 strains in this study were isolated in the mid-1980s in a rural region (Cravioto et al., 1990). It is believed that the changes in antimicrobial resistance observed in the Mexican E. coli strains in this study are associated with the indiscriminate use of these antimicrobial agents resulting in the selec- tion of resistant strains, especially those resistant to the fluoroquinolones.

The overall findings of this study indicate that E. coli 64474:H2, E. coli 64474:H10, E. coli 64474:H32 and E. coli 64474 : H34 belong to a new serogroup with at least four different pathogenic serotypes showing a somatic antigen identical to that of $S$. boydii 16 and having the pathogenic characteristics of ETEC strains, with a wide geographical distribution. The existence of this type of $E$. coli strain opens up a new discussion as to whether these strains are an antigenic variant of $S$. boydii 16 or whether these strains are primarily composed of ETEC with an $S$. boydii $16 \mathrm{O}$ antigen. Studies are under way to answer these questions.

\section{ACKNOWLEDGEMENTS}

We thank Delia Licona, Luis Antonio León and Gabriel Pérez (Facultad de Medicina, UNAM) for their technical assistance in the laboratory. We are particularly grateful to Dr Stephen Savarino for providing us with the E. coli strains from Egypt. This work was supported by grants from SAGARPA-CONACYT 210 and DGAPA/ PAPIIT IN211708 (UNAM). The International Centre for Diarrhoeal Disease Research, Bangladesh (ICDDR, B) is supported by donor countries and agencies, which provide unrestricted support to the centre for its operation and research.

\section{REFERENCES}

Amábile-Cuevas, C. F., Arredondo-García, J. L., Cruz, A. \& Rosas, I. (2010). Fluoroquinolone resistance in clinical and environmental isolates of Escherichia coli in Mexico City. J Appl Microbiol 108, 158162.

Bekal, S., Brousseau, R., Masson, L., Prefontaine, G., Fairbrother, J. \& Harel, J. (2003). Rapid identification of Escherichia coli pathotypes by virulence gene detection with DNA microarrays. J Clin Microbiol 41, 2113-2125.

Barrow, G. I. \& Feltham, R. K. A. (1993). Cowan and Steel's Manual for the Identification of Medical Bacteria, 3rd edn. Cambridge: Cambridge University Press.

Chapman, P. A., Siddons, C. A., Gerdan Malo, A. T. \& Harkin, M. A. (1997). A 1-year study of Escherichia coli O157 in cattle, sheep, pigs and poultry. Epidemiol Infect 119, 245-250.

Coimbra, R. S., Grimont, F. \& Grimont, P. A. D. (1999). Identification of Shigella serotypes by restriction of amplified O-antigen gene cluster. Res Microbiol 150, 543-553.

Coimbra, R. S., Grimont, F., Lenormand, P., Burguière, P., Beutin, L. \& Grimont, P. A. D. (2000). Identification of Escherichia coli $\mathrm{O}$-serogroups by restriction of the amplified $\mathrm{O}$-antigen gene cluster ( $r f b$-RFLP). Res Microbiol 151, 639-654.

Cravioto, A., Reyes, R. E., Trujillo, F., Uribe, F., Navarro, A., De La Roca, J. M., Hernández, J. M., Pérez, G. \& Vázquez, V. (1990). Risk of diarrhea during the first year of life associated with initial and subsequent colonization by specific enteropathogens. Am J Epidemiol 131, 886-904.

Davidson, G., Barnes, G., Bass, D., Cohen, M., Fasano, A., Fontaine, O. \& Guandalini, S. (2002). Infectious diarrhea in children: working group report of the First World Congress of Pediatric Gastroenterology, Hepatology, and Nutrition. J Pediatr Gastroenterol Nutr 35, S143-S150. 
ESNC-IAMS (1958). Supplement to the third report on the Shigella group. Int Bull Bacteriol Nomencl Taxon 8, 93-95.

Escobar-Páramo, P., Giudicelli, C., Parsot, C. \& Denamur, E. (2003). The evolutionary history of Shigella and enteroinvasive Escherichia coli revised. J Mol Evol 57, 140-148.

Estrada-García, T., Cerna, J. F., Pacheco-Gil, L., Velázquez, R. F., Ochoa, T. J., Torres, J. \& DuPont, H. L. (2005). Drug-resistant diarrheogenic Escherichia coli, Mexico. Emerg Infect Dis 11, 13061308.

Ewing, W. H. (1986). Edwards and Ewing's Identification of Enterobacteriaceae. New York: Elsevier.

Goering, R. V. (1993). Molecular epidemiology of nosocomial infection: analysis of chromosomal restriction fragment patterns by pulsed-field gel electrophoresis. Infect Control Hosp Epidemiol 14, 595-600.

Gogarten, J. P., Doolittle, W. F. \& Lawrence, J. G. (2002). Prokaryotic evolution in light of gene transfer. Mol Biol Evol 19, 2226-2238.

Hancock, D. D., Besser, T. E., Rice, D. H., Herriott, D. E. \& Tarr, P. I. (1997). A longitudinal study of Escherichia coli O157 in fourteen cattle herds. Epidemiol Infect 118, 193-195.

Heuzenroeder, M. W., Elliot, T. R., Thomas, C. J., Halter, R. \& Manning, P. A. (1990). A new fimbrial type (PCFO9) on enterotoxigenic Escherichia coli $\mathrm{O} 9: \mathrm{H}^{-} \mathrm{LT}^{+}$isolated from a case of infant diarrhea in central Australia. FEMS Microbiol Lett 66, 55-60.

Jonsson, K. H. M., Weintraub, A. \& Widmalm, G. (2006). Structural studies of the $\mathrm{O}$-antigenic polysaccharides from Shigella dysenteriae type 3 and Escherichia coli O124, a reinvestigation. Carbohydr Res 341, 2986-2989.

Kotloff, K. L., Winickoff, J. P., Ivanoff, B., Clemens, J. D., Swerdlow, D. L., Sansonetti, P. J., Adak, G. K. \& Levine, M. M. (1999). Global burden of Shigella infections: implications for vaccine development and implementation of control strategies. Bull World Health Organ 77, 651-666.

Landersjö, C., Weintraub, A. \& Widmalm, G. (1996). Structure determination of the $\mathrm{O}$-antigen polysaccharide from the enteroinvasive Escherichia coli (EIEC) O143 by component analysis and NMR spectroscopy. Carbohydr Res 291, 209-216.

Li, Y., Cao, B., Liu, B., Liu, D., Gao, O., Peng, X., Wu, J., Bastin, D. A., Feng, L. \& Wang, L. (2009). Molecular detection of all 34 distinct Oantigen forms of Shigella. J Med Microbiol 58, 69-81.

Linnerborg, M., Wollin, R. \& Widmalm, G. (1997). Structural studies of the O-antigenic polysaccharide from Escherichia coli O167. Eur J Biochem 246, 565-573.

Liu, B., Senchenkova, S. N., Feng, L., Perepelov, A. V., Xu, T., Shevelev, S. D., Zhu, Y., Shashkov, A. S., Zou, M. \& other authors (2006). Structural and molecular characterization of Shigella boydii type $16 \mathrm{O}$ antigen. Gene 380, 46-53.

Liu, B., Knirel, Y. A., Feng, L., Perepelov, A. V., Senchenkova, S. N., Wang, Q., Reeves, P. R. \& Wang, L. (2008). Structure and genetics of Shigella $\mathrm{O}$ antigens. FEMS Microbiol Rev 32, 627-653.

Matushek, M. G., Bonten, M. J. M. \& Hayden, M. K. (1996). Rapid preparation of bacterial DNA for pulsed-field gel electrophoresis. J Clin Microbiol 34, 2598-2600.

Ménard, R., Prévost, M. C., Gounon, P., Sansonetti, P. \& Dehio, C. (1996). The secreted Ipa complex of Shigella flexneri promotes entry into mammalian cells. Proc Natl Acad Sci U S A 93, 1254-1258.

Nataro, J. P. \& Kaper, J. B. (1998). Diarrheagenic Escherichia coli. Clin Microbiol Rev 11, 142-201.

Ørskov, F. \& Ørskov, I. (1984). Serotyping of Escherichia coli. In Methods in Microbiology, vol. 14, pp. 43-112. Edited by T. Bergan. London: Academic Press.
Paniagua, M., Espinoza, F., Ringman, M., Reizenstein, E., Svennerholm, A. M. \& Hallander, H. (1997). Analysis of incidence of infection with enterotoxigenic Escherichia coli in a prospective cohort study of infant diarrhea in Nicaragua. J Clin Microbiol 35, 1404-1410.

Peng, J., Yang, J. \& Jin, Q. (2009). The molecular evolutionary history of Shigella spp. and enteroinvasive Escherichia coli. Infect Genet Evol 9, 147-152.

Perepelov, A. V., Wang, Q., Senchenkova, S. N., Shevelev, S. D., Zhao, G., Shashkov, A. S., Feng, L., Knirel, Y. A. \& Wang, L. (2006). Structure of a teichoic acid-like O-polysaccharide of Escherichia coli O29. Carbohydr Res 341, 2176-2180.

Perepelov, A. V., Liu, B., Senchenkova, S. N., Shashkov, A. S., Feng, L., Knirel, Y. A. \& Wang, L. (2008a). Structure of the O-polysaccharide of Escherichia coli O112ab containing L-iduronic acid. Carbohydr Res 343, 571-575.

Perepelov, A. V., Weintraub, A., Liu, B., Senchenkova, S. N., Shashkov, A. S., Feng, L., Wang, L., Widmalm, G. \& Knirel, Y. A. (2008b). The O-polysaccharide of Escherichia coli O112ac has the same structure as that of Shigella dysenteriae type 2 but is devoid of Oacetylation: a revision of the $\mathrm{S}$. dysenteriae type $2 \mathrm{O}$-polysaccharide structure. Carbohydr Res 343, 977-981.

Pupo, G. M., Lan, R. \& Reeves, P. R. (2000). Multiple independent origins of Shigella clones of Escherichia coli and convergent evolution of many of their characteristics. Proc Natl Acad Sci U S A 97, 1056710572.

Qadri, F., Das, S. K., Faruque, A. S., Fuchs, G. J., Albert, M. J., Sack, R. B. \& Svennerholm, A.-M. (2000). Prevalence of toxin types and colonization factors in enterotoxigenic Escherichia coli isolated during a 2-year period from diarrheal patients in Bangladesh. J Clin Microbiol 38, 27-31.

Qadri, F., Svennerholm, A.-M., Faruque, A. S. G. \& Sack, R. B. (2005). Enterotoxigenic Escherichia coli in developing countries: epidemiology, microbiology, clinical features, treatment, and prevention. Clin Microbiol Rev 18, 465-483.

Raetz, C. R. H. \& Whitfield, C. (2002). Lipopolysaccharide endotoxins. Annu Rev Biochem 71, 635-700.

Reid, S. D., Herbelin, C. J., Bumbaugh, A. C., Selander, R. K. \& Whittam, T. S. (2000). Parallel evolution of virulence in pathogenic Escherichia coli. Nature 406, 64-67.

Rolland, K., Lambert-Zechovsky, N., Picard, B. \& Denamur, E. (1998). Shigella and enteroinvasive Escherichia coli strains are derived from distinct ancestral strains of E. coli. Microbiology 144, 2667-2672.

Scheutz, F., Cheasty, T., Woodward, D. \& Smith, H. R. (2004). Designation of O174 and O175 to temporary O groups OX3 and OX7, and six new E. coli $\mathrm{O}$ groups that include verocytotoxinproducing E. coli (VTEC): O176, O177, O178, O179, O180 and O181. APMIS 112, 569-584.

Schubert, S., Darlu, P., Clermont, O., Wieser, A., Magistro, G., Hoffmann, C., Weinert, K., Tenaillon, O., Matic, I. \& Denamur, E. (2009). Role of intraspecies recombination in the spread of pathogenicity islands within the Escherichia coli species. PLoS Pathog 5, e1000257.

Schultsz, C., Pool, G. J., van Ketel, R., de Wever, B., Speelman, P. \& Dankert, J. (1994). Detection of enterotoxigenic Escherichia coli in stool samples by using nonradioactively labeled oligonucleotide DNA probes and PCR. J Clin Microbiol 32, 2393-2397.

Sjöling, A., Wiklund, G., Savarino, S. J., Cohen, D. I. \& Svennerholm, M.-A. (2007). Comparative analyses of phenotypic and genotypic methods for detection of enterotoxigenic Escherichia coli toxins and colonization factors. J Clin Microbiol 45, 3295-3301. 
Tominaga, A., Lan, R. \& Reeves, P. R. (2005). Evolutionary changes of the flhDC flagellar master operon in Shigella strains. J Bacteriol 187, 4295-4302.

Venkatesan, M. M., Goldberg, M. B., Rose, D. J., Grotbeck, E. J., Burland, V. \& Blattner, F. R. (2001). Complete DNA sequence and analysis of the large virulence plasmid of Shigella flexneri. Infect Immun 69, 3271-3285.

Wang, L. \& Reeves, P. R. (1998). Organization of Escherichia coli $\mathrm{O} 157 \mathrm{O}$ antigen gene cluster and identification of its specific genes. Infect Immun 66, 3545-3551. 